\title{
Proximate and Phytochemical Analysis of Monodora myristica (African Nutmeg) from Nsukka, Enugu State, Nigeria
}

\author{
Nkwocha Chinelo C. ${ }^{1, *}$, Nworah Florence N. ${ }^{1}$, Okagu Innocent U. ${ }^{1}$, Nwagwe Onyinyechi R. ${ }^{2}$, \\ Uchendu Nene O. ${ }^{1}$, Paul-Onyia Dawn $B^{1}$, Obeta Sunday ${ }^{1}$ \\ ${ }^{1}$ Department of Biochemistry, University of Nigeria, Nsukka, Enugu State, Nigeria \\ ${ }^{2}$ Department of Biochemistry, Federal University, Oye-Ekiti, Ekiti State, Nigeria \\ *Corresponding author: austinelonwa@gmail.com
}

Received August 17, 2018; Revised September 19, 2018; Accepted October 07, 2018

\begin{abstract}
This study was carried out to determine the proximate composition and phytochemical (qualitative and quantitative) analysis of ground seeds of Monodora myristica (African nutmeg)which was obtained from Nsukka, Enugu state. The proximate and phytochemical analysis of the seeds was carried out by using the standard methods. Results from the study show that the mean values of various parameters for the proximate composition were $(14.50 \pm 0.52 \%)$ moisture, $(2.50 \pm 0.50 \%)$ total ash, $(16.00 \pm 1.00 \%)$ crude lipid, $(12.09 \pm 0.52 \%)$ crude protein, $(19.00 \pm 1.00 \%)$ crude fibre and (35.92\%) carbohydrate. Qualitative phytochemical analysis showed that steroids was detected in high amount, saponin and terpenoids were detected in moderate amount while tannin, phenol and alkaloid were detected in low amount. Anthocyanins, glycoside and anthroquinone were not detected. Also the result of the study showed that steroid was detected in high amount $(32.75 \pm 5.42 \%)$, saponinns $(12.04 \pm 3.33 \%)$ and terpenoid $(19.00 \pm 3.18 \%)$ were detected in moderate amount, alkaloid $(2.75 \pm 0.82 \%)$, and phenol $(0.46 \pm 0.10 \%)$ was detected in low amount.
\end{abstract}

Keywords: monodora myristica, proximate, phytochemical, seeds

Cite This Article: Nkwocha Chinelo C., Nworah Florence N., Okagu Innocent U., Nwagwe Onyinyechi R., Uchendu Nene O., Paul-Onyia Dawn B, Obeta Sunday, and Onwudiwe Nwanneka, "Proximate and Phytochemical Analysis of Monodora myristica (African Nutmeg) from Nsukka, Enugu State, Nigeria.” Journal of Food and Nutrition Research, vol. 6, no. 9 (2018): 597-601. doi: 10.12691/jfnr-6-9-9.

\section{Introduction}

Monodora myristica is a perennial edible plant of the Annanacea family, which grows wild in the evergreen forest of West Africa [1]. It is widely distributed from Africa to Asia, Central and South America [2]. Monodora myristica has its common names as African nutmeg, calabash nutmeg, and in Nigeria, it is called "Ehuru" in Igbo, "Abolakoshe" in Yoruba and "Ebenoyoba" in Benin [3]. In addition, the bark, seeds and leaves are used in treating various ailments in African traditional medicine [4]. However, the most economically important parts are the seeds, which are embedded in the white sweet smelling pulp of the sub-spherical fruit [5]. The seeds have nutritive and calorific values, which makes them necessary in diets [6]. The kernel obtained from the seed has an aromatic fragrance, which makes it suitable as a spicing agent for both African and continental cuisines in Nigeria [7]. In eastern countries, it is used as a drug more than a condiment. When it was roasted and grounded, seeds are rubbed on the skin for treatment of skin diseases [8]. This suggests that the seeds of Monodora myristica plant could be germicidal or antiseptic [9]: It can be used for the treatment of constipation and as a stimulant [8]. Grinding into powder, the seed may be taken as a stimulant to relieve constipation and control passive uterine hemorrhage in women immediately after child birth [10]. The essential oil from the seed is used in pharmaceutical and dental preparation [11], the stem bark of Monodora myristica is used in the treatment of haemorrhoids, stomach ache, fever pains and eye diseases [12]. The nutrient contents of the seed, from different locations have been reported [1,7,13]. To our knowledge, there has not been any report of seeds from Nsukka. The authors hypothesize that environmental condition, the type and nutritive status of soil have the impact on the proximate and phytochemical composition of plant seeds. This study was therefore aimed at the determination of the proximate and phytochemical compositions of Monodora myristica seeds from Nsukka, Enugu State, Nigeria which compared the availability and levels with that obtained from other part of the world as reported in literature. 


\section{Materials and Methods}

\subsection{Materials}

\subsubsection{Plant Material}

Seed of plant material, Monodora myristica, was dried.

\subsubsection{Collection and Authentication of Plant Material}

Fresh seeds of Monodora myristica were purchased at Nkwo-Ibagwa market in Nsukka, Enugu state and were authenticated by Dr. C. Njokuocha of the Department of Plant Science and Biotechnology, University of Nigeria, Nsukka, Enugu State, Nigeria. Voucher specimen was deposited in the herbarium of the Department.

\subsubsection{Chemicals and Reagents}

All chemicals used were of analytical grade and were products of May and Baker (England). Reagents used for the analysis were all Sigma products (USA).

\subsubsection{Equipment and Instruments}

All apparatus used in this study were got from the Laboratory Unit of Departments of Biochemistry, Food Science and National Centre for Energy Research, all in University of Nigeria, Nsukka.

\subsection{Methods}

\subsubsection{Preparation of Plant Material for Analysis}

Fresh seeds of Monodora myristica were de-hulled (the coat removed), and rid of bad seeds and dirt. The seeds were then taken to a drying room for 14 days to remove the water contents. Thereafter, the seeds were milled to fine powder by using manual engine grinder (Model Corene, A.5 lander YCIA S.A) on the $14^{\text {th }}$ day.

\subsubsection{Proximate Analysis}

The proximate analysis of the sample for moisture, crude protein, fat, ash and fibre contents were carried out in duplicate by using Official Methods [14]. Carbohydrates were determined by the difference method. All the proximate values were reported in percentages.

\subsubsection{Phytochemical Analysis of Powdered Sample of Monodora myristica Seeds}

The phytochemical analyses of powdered sample of Monodora myristica seeds were carried out according to the methods, which described by [15] and [16].

\section{Results and Discussion}

Table 1. PROXIMATE COMPOSITION OF MONODORA MYRISTICA SEED FLOUR

\begin{tabular}{ll}
\hline Proximate parameters & Composition (\%) \\
\hline Crude protein & $12.09 \pm 0.52$ \\
Moisture & $14.50 \pm 0.50$ \\
Total ash & $2.50 \pm 0.50$ \\
Crude lipid & $16.00 \pm 1.00$ \\
Crude fibre & $19.00 \pm 1.00$ \\
Carbohydrate & $35.92 \pm 0.50$ \\
\hline
\end{tabular}

Values are mean \pm standard deviation of duplicate determinations.
Even though the seeds are used as spices, the carbohydrate and lipid contents as shown in Table 1. It was quite appreciable and could be regarded as good sources of carbohydrate and especially essential oils for the body. The anti-hypertensive effect of essential oils derived from seeds of Monodora myristica have earlier been studied [17]. According to phytochemical analysis, the essential oil contains mainly monoterpenoids, which indicate that it exerts an anti-hypertensive activity. Essential oils derived from the cotyledons of such seeds, showing high saponification value, low iodine and acid values. Therefore, it could be used for their medicinal and antioxidant properties [18].

The crude lipid with amount of $16 \% \pm 1.0$ is low compared to this reported [19] (25.00\%), [13] (29.10\%), [20] (22.70\%) and [21] (24.33\%) but high amount of crude lipid when compared to this reported by [22] (6.34\%). The variation in the values may be caused by changes in climatic factors and stages of maturity of seed used. Amount of crude lipid was also low when compared to the varieties of melon seeds, which ranged between 47.9-51\% reported by [24], for pumpkin seed (49.2 and $47.01 \%)$ by [23] and [24], cashew nut (36.7\%) by [25] and soya bean seed (23.5\%) [26]. Therefore, the production of oil from Monodora myristica may be too expensive. Hence, it is not economical. Fat is important in diets because it promotes fat soluble vitamin absorption [27]. It is a high energy nutrient and does not add to the bulk of the diet.

Amount of $12.09 \pm 0.52 \%$ for crude protein is corresponded to the report by [19] (12.00\%), [13] (10.13\%) and [20] $(9.60 \%)$ but it does not correspond with the reports by [22] (22.77\%) and [21] (18.69\%). Such differences may arise from variations in soil micronutrients [28]. It could also be partly attributed to the method of analysis. The crude protein value is relatively low when compared to protein rich foods, such as soybeans, cowpeas, pigeon peas, melon and gourd seeds that ranged between 23.1 and 33.0\% [29] chick beans (19.4\%) and lima bean (19.8\%) and jack bean-30.8\% [30]. However, it could be a good source of important enzymes which is the form on which is most proteins in spices [31]. The recommended daily allowance for protein for children ranges from 23.0-36.0g and 44$56 \mathrm{~g}$ for adults [32]. Apart from the significant nutritional protein as a source of amino acids, they also play a part in the organoleptic properties of food [25].

Amount of $14.5 \pm 0.50 \%$ for moisture was in concurrence with the report by [19] (10.00\%), [13] (13.15\%) and [20] $(11.20 \%)$ but this value is higher than those obtained by [22] (8.68\%) and [21] (6.00\%). The difference observed may be as a result of the maturity of seed as well as the method of analysis used. Amount of the moisture was comparable with that of legumes ranging between 7.0 and $11.0 \%$, which reported by [33]. The low moisture content is indicative of the fact that African nutmeg can be stored for a long period without deterioration in quality or microbial spoilage since microbial activity may be reduced to a minimum quantity. Moisture content of any food can be used as an index of its keeping quality. Water is an important media for most biochemical reactions. Food samples with more $15 \%$ for water content are more prone to high biochemical activities. Therefore, it usually have short shelf life [34]. 
Amount of $2.5 \% \pm 0.5$ for ash content was corresponded to the observation of [13] (3.90\%) and [20] (2.50\%). The reports by [19] (5.00\%), [22] (8.61\%) and [21] (4.90\%) were higher than those of this investigation. Consequently, this could be caused by changes in the climatic factors in addition to edaphic factors. This amount of ash value was very low though it was slightly lower than that of Brachetagia eurycoma (8.35\%). It has been recommended by [35] that ash contents of nuts, seeds and tubers should fall within the range of $1.5-2.5 \%$ in order to be suitable for animal feeds. The ash content of African nutmeg seed falls within this range. Therefore, it can be recommended for animal feeds. Ash content refers to the inorganic residues which remained after either ignition or complete oxidation of organic matter in the sample, and gives an overview of mineral content of the material [34]. High amount of ash implies high mineral contents in the spices. Monodora myristica is not likely to be a good source of minerals in human diet. Nutritionally, ash aids in the metabolism of protein, carbohydrate and fat [36].

Amount of $19.00 \pm 1.00$ for crude fibre content was corresponded to the report by [20] $(19.10 \%)$ but it was vastly different from the reports by [19] (8.33\%), [13] (25.90\%), [22] (5.25\%) and [21] (3.30\%). The variation of the results may be caused by changes in climatic factors and stages of maturity of seed used. However the fibre content from this observation in this investigation is relatively high quantity. This implies that when this seed is incorporated into food, it will help to prevent many metabolic or digestive disorders such as constipation and irritable bowels, etc. [37]. The content of the crude fiber was very high compared to legumes, which was ranged between 5 and 6\% [25]. Therefore, African nutmeg was a good source of dietary fiber. Dietary fibers are generally plant polysaccharides that can not be digested by human digestive enzymes. Dietary fibres are either soluble or insoluble, both modulate physiological function and prevent some degenerative diseases in human. Dietary fibre causes variations of water content in faecal, faecal bulk, transit time and elimination of bile acids and neutral sterols, which lowers the body's cholesterol pool. Therefore, the dietary fibers have been shown to reduce the incidence of coronary and breast cancer [38,39].

For the percentage carbohydrate content, it was accounted with $35.92 \pm 0.50 \%$, which was in concurrence with the reports by [19] but it was different from the reports by [20] (28.40\%), [13] (21.20\%), [22] (46.90\%) and [21] (42.78\%). The variation of the results was most likely to be introduced by the method of analysis for other components. The carbohydrate content was very larger than that of cassava seed (16.81\%) [37]. This content was also comparable to the acceptable range of legumes (20-60\%) based on dry weight [33]. Hence, seeds are a good source of energy for animals when they are incorporated into diet. Carbohydrate provides energy to cells, particularly the brain, which depended on the carbohydrate content [38].

Table 2 and Table 3 show that Monodora myristica contained high amount of steroids (32.75 $\pm 5.42 \%)$. This was corresponded to the report by [13], which showed high content of steroids in seeds of the plant. The investigations by [20] and [38] have not found steroids in
Monodora myristica.. This variation could be attributed to the differences in the analytical method used. Saponins

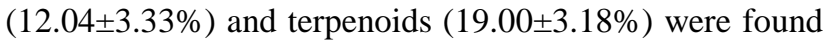
in moderately high amounts. This corresponded to the observation made by [13]. Ref [38] detected saponins in high amounts while [20] has been found saponins content. This could partly be attributed to climatic conditions. However, the variations in methods of analysis used could be the main reason. Such compounds can reduce the content of glucose and glycerol uptake in the gut whereas terpenoid inhibits the release of autocoids and prostaglandins [40]. Alkaloid (2.75 $\pm 0.82 \%)$, phenol $(0.46 \pm 0.10 \%)$, and tannins contents $(0.51 \pm 0.03 \%)$ were found in low amounts. Such content in concurrence with the reports by [13] and [20], which its content were found in low amount of tannins. The report of [20] found the high amount of phenols. The research of [38] and [20] were found alkaloids in high and moderate contents. On the other hand, the research of [13] has not been found alkaloids. Several factors could lead to this variation. The use of sun dried the seeds in an open environment for five days by [20], which differed from the method of using airdrying for fourteen (14) days. Such method could cause the variation for amount of alkaloid, phenol and tannin in Monodora myristica seeds. Alkaloids and their synthetic derivatives are used as basic medicinal agent for their analgesic, antispasmodic and antibacterial effect [41]. Alkaloids also bind to adhesins, enzyme inhibition, substrate deprivation, complex with cell wall, membrane disruption, metal ion complexation [41]. Phenol makes intestinal mucosa more resistant and reduces secretion, stimulation against normalization of deranged water transport across the mucosal cells and reduction of the intestinal transit, blocking the binding of $\mathrm{B}$ subunit of heat-labile enterotoxin to GM. The result could suppress the symptoms of heat-labile enterotoxin-induced diarrhoea and astringent action. It was contributed in the animals of digestible proteins by forming protein complexes in rumen, interfering in the generation of energy by uncoupling oxidative phosphorylation, the causes of reduction in gastrointesinal metabolism [40]. Due to antimicrobial and antioxidant activities of tannins, they can increase antioxidant activity, prevention against proliferation of cancer and promoting the apoptotic carcinogenic cell [40].

Table 2. QUALITATIVE PHYTOCHEMICAL PROFILE OF MONODORA MYRISTICA SEEDS

\begin{tabular}{ll}
\hline Phytochemicals & Abundance \\
\hline Alkaloids & + \\
Anthocyanins & - \\
Saponins & ++ \\
Terpenoids & ++ \\
Steroids & + \\
Tannins & + \\
Phenols & ++ \\
Flavonoids & - \\
Anthocyanins & - \\
\hline
\end{tabular}

Key:- = not detected

$+=$ detected in low amount

$++=$ detected in moderate amount

$+++=$ detected in high amount 
Table 3. QUANTITATIVE PHYTOCHEMICAL CONTENTS OF MONODORA MYRISTICA SEEDS

\begin{tabular}{ll}
\hline Phytochemicals & Amount (\%) \\
\hline Alkaloids & $2.75 \pm 0.82$ \\
Anthocyanins & $0.00 \pm 0.00$ \\
Saponins & $12.04 \pm 3.33$ \\
Terpenoids & $19.00 \pm 3.18$ \\
Steroids & $32.75 \pm 5.42$ \\
Tannins & $0.51 \pm 0.03$ \\
Phenols & $0.46 \pm 0.10$ \\
Flavonoids & $0.00 \pm 0.00$ \\
Anthocyanins & $0.00 \pm 0.00$ \\
\hline
\end{tabular}

Values are mean \pm standard deviationof duplicate determinations.

Flavonoids, anthroquinones, anthocyanins involving some glycosides have not been found and glycosides in the analysis. The research work of [38] and [13] found large amounts of flavonoids whereas [20] has been found the low content of flavonoids. In the same way, the research of [20] showed a moderate content of anthroquinones. Likewise, some glycosides have been found in moderate and low contents by [38] and [13]. This variation could be attributed to many factors, such as climatic, edaphic and time of exposure to dryness. Such differences may arise from variations in soil micronutrients. It could also be partly attributed to the method of analysis [42,43,44].

Phytochemical analysis revealed flavonoids, anthraquinones, saponins, phenols, tannins, alkaloids, anthocyanin, glycosides, and terpenoid. The seeds may be a source of antioxidants. For potent antioxidant property of flavonoids (phytoestrogens), it revealed their ability of scavenge hydroxyl radicals $\mathrm{OH} \bullet$, superoxide anions $\mathrm{O}_{2} \bullet-$ and lipid peroxy radicals. Moreover, phenols are strong antioxidants that prevent oxidative damage to biomolecules, e.g., deoxyribonucleic acid (DNA), lipids, and proteins, which play a role in chronic diseases, e.g., cancer and cardiovascular disease. Plant phenols interfere with all stages of cancer, potentially resulting in a reduction of risk.

\section{Conclusion}

The relatively high nutritive values of African nutmeg may be of little importance in everyday life since the quantity of this spice using in cuisine is relatively very small. African nutmeg is consumed in as food ingredients in low content, and its contribution to nutrition in diet may not be as high as the staple food items. However, many rural consumers use $M$. myristica seed flour copiously in various local dishes. Hence it can make meaningful nutritional contribution in diet. Generally, it contributes to food cuisine nutritionally and imparts many health benefits. Conclusively, it should be noted that the seeds of $M$. myristica contained some important nutritional components. Furthermore, the study need to require the isolation, identification and characterization of active components in the plant seed in order to maximize the medicinal and nutrition property. This work basis on bio-prospecting approach for drugs and chemicals. In addition, the $M$. myristica seed contains oil in appreciable quantity, which can be used industrially.

\section{References}

[1] Burubai, W., Amula, E., Daworiye, P., Suowari, T. and Nimama P. (2009). Proximate composition and some technological properties of African nutmeg (Monodora myristica) seeds. Electronic Journal of Environment, Agricultural and Food Chemistry, 8: 396-402.

[2] Omobuwajo, T.O, Omobuwajo, O.R. and Sanni, L.A (2003). Physical properties of calabash nutmeg (Monodora myristica) seeds Journal Food Engineering, 57: 375-381.

[3] Akinwunmi, K.F. and Oyedepo, O.O. (2013). Evaluation of antioxidant potentials of Monodora myristica (Gaertn) dunel seeds. African Journal of Food Science, 7(9): 317-324.

[4] Erukainure, O.L., Oke, O.V., Ajiboye, A.J. and Okafor, O.Y. (2011). Nutritional qualities and phytochemical constituents of Clerodendrum volubile, a tropical non-conventional vegetable. Food Research Journal, 18(4): 1393-1399.

[5] Hemingway, C. (2004). Plants and people. Edible Plant Journal, 1 p.1.

[6] Odoemelam, S.A. (2005). Proximate composition and selected physicochemical properties of the seeds of African oil bean (Pentaclethra marcrophylla). Pakistan Journal, 6: 82-85.

[7] Dike, M.C. (2010). Proximate, photochemical and nutrient composition of some fruits, seeds and leaves of some plant species in Umudike, Nigeria. Journal of Agricultural and Biological Science, 5: 7-16.

[8] Irvine, F.R. (2000). Woody plants of reference to their uses. Oxford University Press, London. pp. 13-23.

[9] Rancy, A.T. and Krishnakumari, S. (2015). Proximate analysis and mineral composition of Monodora myristica seeds. Journal of Pharmacognosy and Phytochemistry, 3(6): 39-42.

[10] Udeala, O.K. (2000). Preliminary evaluation of dike fat, a new tablet lubricants. Journal of Pharmacology, 32: 6-9.

[11] Talalaji, S.J. (1999). Essential oil from Monodora myrisitica grown in Ghana West African Pharmacist, 4: 84-65.

[12] Singh, G., Marimuth, P., Heluani, D. and Catalan, C. (2005). Antimicrobial and antioxidant potentials of essential oil and acetone extract of Monodora myristica. Journal of Food Science, 70(2): 141-148.

[13] Ekeanyanwu, C. R., Ugu, I. G. and Nwachukwu, U. P. (2010). Biochemical characteristics of the African nutmeg, Monodora myristica from Nigeria. African Journal of Biochemical Research, 6(9): 115-120.

[14] AOAC (2000). Official method of analysis. $16^{\text {th }}$ Edition. Association of Official Analytical Chemists, Washington DC., USA. pp. 200-210.

[15] Harbone, J.B. (1998). Phytochemicals methods. Chapman and Hall Ltd., London. pp. 49-188.

[16] Trease, G. E. and Evans, W. C. (2002).Trease and Evans Pharmacognosy. $4^{\text {th }}$ Edn. W. B Saunders, USA: 820-835.

[17] Koudou, J., Etou Ossibi, A. W., Aklikokou, K., Abenna, A. A., Gbeassor, M., Bessiere, J. M. (2007). Chemical composition and hypotensive effects of the essential oil of Monodora myristica gaertn. Journal of Biological Science, 7: 937-942.

[18] Ayelaagbe, O., Ajaiyeoba, E. and Ekundayo, O. (1996). Studies on the seed oil of Parkia biglobosa and Parkia bicolor. Journal of Plant Foods for Human Nutrition, 46: 229-233.

[19] Faleyimu, O. and Oluwalana, S. (2008). Proximate analysis of Monodora myristica (Gaertn.) dunal (African nutmeg) in Ogun state, Nigeria. World Journal of Biological Research, 001: p.2.

[20] Enabulele, S. A., Oboh, F. O. and Uwadiae, E. O. (2014). Antimicrobial, nutritional and phytochemical properties of Monodora Myristica Seeds. IOSR Journal of Pharmacy and Biological Sciences, 9(4): 1-6.

[21] Enwereuzoh, R., Okafor, D., Uzoukwu, A., Ukanwoke, M., Nwakaudu, A., and Uyanwa, C. (2015). Flavour extraction from Monodora myristica and tetrapleura tetraptera and production of flavoured popcorn from the extract. European Journal of Food Science and Technology, 3(2): 1-17.

[22] Ugwuona, F. U. (2014). Phytochemical composition, antioxidant and antimicrobial properties of four Nigerian spices. M.Sc. Thesis, University of Nigeria, Nsukka.

[23] Asiegbu, I. (1987). Some biochemical evaluation of fluted pumpkin seed. Journal of the Science of Food and Agriculture, 40: 151-155. 
[24] Fagbemi, T. N. and Oshodi, A. (1991). Chemical composition and functional properties of full-fat fluted pumpkin seed flour (Telfairia occidentalis). Nigerian Food Journal, 9: 26-32.

[25] Aremu, M., Olonisakin, A., Bako, D. and Madu, P. (2006). Compositional studies and physicochemical characteristics of cashew nut (Anarcadium occidentale) flour. Pakistan Journal of Nutrition, 5: 328-333.

[26] Paul, A. A. and Southgate, B. (1980). Mucance and widdowson's consumption of food ( $4^{\text {th }}$ Edition). Her majesty's stationary office, London, UK

[27] Bogert, J., Briggs, G. and Galloway, D. (1994). Nutrition and physical fitness. International Journal of Food Science and Nutrition, 45: 223-230.

[28] Okwu, D.O (2001). Evaluation of the chemical composition of indigenous spices and flavouring agents. Global Journal of Pure and Applied Science, 7(3): 445-459.

[29] Olaofe, O., Adeyemi, F. and Adediran, G. (1994). Amino acid and mineral composition and functional properties of some oil seeds. Journal of Agricultural and Food Chemistry, 42: 878-884.

[30] FAO (1982). Composition table for use in Africa. Development of Health Education and Welfare. Health Science and FAO Division. p.32.

[31] Wills, R. McGlasson, B. Graham, D. and Joyce, D. (1998). Postharvest an introduction to the physiology and handling of fruit vegetables and ornamentals ( $4^{\text {th }}$ Edition). CAB International, England. pp. 15-32.

[32] NRC. (1989). Recommended Dietary Allowances (10 $0^{\text {th }}$ Edition). National academy press, Washington, DC.

[33] Aykroyd, W. K. and Doughty, J. (1964). Legumes in human nutrition. Food and Agriculture Organization of the United Nations, p.125.

[34] Joslyn, M.N. (1970). Methods in food analysis, Academic press, New York. pp. 20-22.

[35] Pomeranz, V. and Clifton, D. (1981). Properties of defatted soybean, peanut, field pea and pecan flours. Journal of Food Science, 42: 1440-1450.

[36] Okaka, J. C. (2005). Handling, storage and processing of plant food. OCJANCO academic publishers, Enugu, Nigeria. pp. 250-270.
[37] Akinlawon, O.A, 1998: Biochemical analysis of Brachystegia seed. SLT project. Moshood Abiola Polytechnic, Abeokuta, Ogun State.

[38] Effiong, G.S., Ibia, I.O. and Udofia, U.S. (2005). Nutritive and energy values of some wild fruit spices in south-eastern Nigeria. Electronic Journal of Environment, Agricultural and Food Chemistry, 8(10): 917-923.

[39] Lintas, C. (1992). Nutritional aspect of fruits and vegetables consumption options. Mediterraunnes, 19: 97-87.

[40] Bachaya, H.A., Iqbal, I., Khan, M.N., Jabbar, J., Gilani, A.H. and Din, I.U. (2009). In vitro and in vivo anthelmintic activity of Terminalia arjunabark. Internal Journal of Agriculture and Biology, 11: 273-278.

[41] Ogukwe, C.E., Oguzie, E.E., Unaegbu, C. and Okolue, B.N. (2004). Phytochemical screening of the leaves of Sansevieratrifasciata Journal of Chemical Society of Nigeria, 29(1): 8-10.

[42] Bimakr, M. (2010). Comparison of different extraction methods for the extraction of major bioactive flavonoid compounds from spearmint (MenthaspicataL.) leaves. Food and Bioproducts Processing, 10: 1-6.

[43] Lapornik, B., Prosek, M. and Wondra, A.G. (2005). Comparison of extracts prepared from plant by-products using different solvents and extraction time. Journal of Food Engineering, 71: 214-222.

[44] Wang, G.X. (2010). In vivo anthelmintic activity of five alkaloids from Macleaya Microcarpa (Maxim) Fedde against Dactylogyrus intermedius in Carassiusauratus. Veterinary Parasitology, 171: 305-313.

[45] Ekeanyanwu, R.C. and Etienajirhevwe, O.F. (2012).In vitro antihelmintic potentials of Xylopia aethiopica and Monodora myristica from Nigeria.Africa Journal of BiochemistryResearch, 6(9): 115-120.

[46] Ige, M. N., Ogunsua, A. O. and Oke, O. I. (1984). Functional properties of the proteins of some Nigerian oil seeds: Casaphor seeds and the three varieties of some Nigerian oil seeds. Journal of Agricultural and Food Chemistry, 32: 822-825. 